\title{
Contamination Of Escherichia Coli Bacteria In School Children's Food (PJAS) In Cakung District Elementary School
}

\author{
Hanifatun Nisa Ath Thoriqoh \\ Public Health Study Program, Faculty of Medicine and Health, UIN Syarif Hidayatullah Jakarta
}

ARTICLE INFO

Keywords:

hygiene, snack food, sanitation

\begin{abstract}
Food is a basic human need that is needed at all times and requires good and correct management so that it does not become a medium for disease transmission. Cakung District is the area with the highest incidence of diarrhea in the 5-9 year age group in East Jakarta in January-June 2016 with 373 cases. Based on a preliminary study, it was found that $87 \%$ of street food in elementary schools in Cakung District was positively contaminated with E.coli bacteria. This study aims to determine the contamination of Escherichia coli bacteria in School Children's Snacks (PJAS) in elementary schools in Cakung District in 2016. The research design used was cross sectional. The sample of this study amounted to 60 food handlers who were taken by cluster sampling. Data analysis was carried out univariate and bivariate using chi square test. The results of this study showed that as many as $45 \%$ of PJAS were positively contaminated with E.coli bacteria. E.coli contamination in food was related to the practice of using food serving aids $(\mathrm{p}=0.044)$, where to store cooked food $(\mathrm{p}=0.007)$ and the way of serving $(\mathrm{p}=0.02)$. However, E.coli contamination was not related to the practice of washing hands with soap $(\mathrm{p}=1.00)$, the method of washing equipment $(p=0.783)$, the type of selling facilities $(p=$ 0.775 ), and the presence of sanitation facilities (1.00). . The school is advised to collect data on traders who sell around the school as well as provide guidance and empowerment by providing stimulants in the form of completeness of selling facilities, such as the provision of sanitation facilities and trash bins.

Copyright (C) 2020 Eduhot Journal.All rights reserved. is Licensed under a Creative Commons Attribution-

NonCommercial 4.0 International License (CC BY-NC
\end{abstract}

E-mail:

hanifatunnisa12@gmail.com

4.0)

1. INTRODUCTION

Food is a basic human need that humans need at all times and requires good and correct management so that it can benefit the body. The problem of food is a problem that must receive special attention in the implementation of overall health[1]. Food safety is one of the things that affect human health. Food can be a medium for transmitting disease to humans if it is contaminated by pathogens that can cause foodborne disease, where the most common case is diarrhea.[2]. The prevalence of diarrhea in Indonesia in the 5-14 year age group was 9\% in 2007 (Kemenkes RI, 2011). In DKI Jakarta Province in 2014, the prevalence of diarrhea in the 5-9 year age group was $2.57 \%$. The area with the highest diarrhea morbidity rate is East Jakarta with the number of diarrhea cases reaching 5,972 cases in 2014 in the 5-9 year age group. Cakung District is the location in East Jakarta with the highest incidence of diarrhea in the 5-9 year age group during January to June 2016 with a total of 373 cases (DKI Health Office Survey, 2016).

Contamination of Escherichia Coli Bacteria in Snack Food for School Children (PJAS) in Cakung District Elementary School, Hanifatun Nisa Ath Thoriqoh 
Diseases caused by food contamination are still widely found as a cause of illness and death in the world. According to WHO (2006), as many as $70 \%$ of cases of diarrhea in developing countries are caused by food contaminated with pathogens. The types of contaminants found in food are bacteria, viruses, parasites, chemicals, and toxins produced by the food itself (WHO, 2015). According to BPOM (2012), contamination in food is mostly caused by bacterial contamination of $74.9 \%$, while other causes are excessive use of BTP in the form of food coloring $15.7 \%$ and the use of hazardous materials by $9 \%$ (Kemenkes, 2015). One of the most common diarrhea-causing bacteria is contamination from Escherichia coli in food or water sources used in food processing.[3]. According to WHO (2006), E.coli bacteria are pathogenic microorganisms that are often found in children with acute diarrhea in developing countries with a percentage of $10-20 \%$, while other bacteria, namely Vibrio cholera by $5-10 \%$ and Salmonella by $1-5 \%$. School children are a group at high risk of contracting disease through food, where the food consumed is purchased at the school canteen or street vendors (WHO, 2006). The school canteen is a special service that provides food and drinks for students and other school staff, in a place that is usually part of the school building.[4]. While street vendors are a group of people who offer goods for sale on sidewalks or on the roadside, around shopping centers/shops, markets, recreation/entertainment centers, office centers and educational centers, either permanently or semi-permanently, with unofficial status. or semi-official and carried out in the morning, afternoon, evening, or evening[5]. Based on the type of Food Management Place (TPM), E.coli contamination in food is most commonly found in street vendors as much as $40.7 \%$, while other places include catering services $38.2 \%$, hotels $33.3 \%$, stalls $32.9 \%$, restaurants $31.3 \%$, and food industry $21.3 \%[6]$.

Snacks sold by school canteens and street vendors are widely liked because of their taste, cheap prices and available at any time[7]. Several studies have shown that the high morbidity rate of diarrhea is caused by not washing hands after defecating, not washing hands before cooking and buying snacks sold by street vendors.[8]. According to the Food and Agricultural Organization (FAO), as many as 2.5 million people eat snacks every day, therefore food processing practices by food handlers play an important role in the safety of street food itself.[9]. The incidence of other foodborne illnesses can occur due to poor personal hygiene practices of traders who sell street food at schools, lodging places and hospitals[10]. Food handlers are carriers or can be a medium of transmission of pathogenic enteric bacteria. According to Bhaskar[4] personal hygieneA bad condition can facilitate the process of contamination of pathogenic bacteria from the environment into the human body through the food eaten. In addition, environmental conditions around the place of sale, such as the presence of sewerage, garbage dumps and puddles of water will make flies and other disease vector animals able to contaminate the food sold by the street vendor.[11]. E.coli contamination in food can come from poor hygiene and sanitation of food handlers, food processing equipment, the condition of the vendors' facilities, to the way food is served. Food sold in school canteens and street vendors around elementary schools can potentially cause foodborne illness due to E.coli contamination, due to poor food hygiene behavior and sanitation conditions. School children are of age who are susceptible to disease, so if the condition of the food consumed is not good, it will affect the process of growth and development of children[12]. For this reason, researchers are interested in examining the contamination of Escherichia coli bacteria in School Children's Snacks (PJAS) in elementary schools in Cakung District.

\section{METHOD}

In this study, the dependent variable studied was the presence of E.coli bacteria in snacks, while the independent variables studied included the practice of washing hands with soap; using food serving aids; how to wash equipment; type of means of selling; a place to store cooked food; and method of presentation. While other variables, such as cleanliness of nails and hands; do not suffer from diarrhea; the presence of a trash can; selection of food ingredients; food storage; processing; and transportation/distribution were not investigated because they were homogeneous. This study is a quantitative analytic study using a cross-sectional design.

The population in this study were all street food vendors selling around elementary schools in Cakung District. The number of samples in this study was 60 food traders who were obtained based 
on the results of the calculation of the sample size. The food samples in this study were 60 snacks, which used a 1:1 ratio, which took 1 type of snack food from 1 food handler. The types of snacks taken are side dishes (heavy snacks), snacks/snacks, and drinks according to the type of food grouping determined by BPOM.

The sampling technique of food handlers in this study used cluster sampling. Cluster sampling was chosen because the research subjects were located in a large geographic area (Walizer and Wienir, 1978). Cakung District can generally be divided into 3 clusters, namely residential areas, large industrial areas and small industrial areas. The determination of the location of the village was chosen randomly representing each cluster, so that the location chosen in this study was in the Kelurahan Cakung Timur, Pulo Gebang and Ujung Menteng.

Laboratory testing is carried out by:

a) Samples that have been brought to the laboratory, then incubated at $360 \mathrm{C}$ for 24 hours.

b) After incubation, take 1 ose of sample and transfer it to a test tube containing LMX media.

c) Add Kovacs reagent into the test tube as much as 5-10 drops.

d) Observing the color change that occurs, if a red ring is formed then the sample is positive for E. coli bacteria. Meanwhile, if no red ring is formed, the sample is negative for E. coli bacteria.

The secondary data in this research are data regarding the addresses of elementary schools and data on street food vendors in Cakung District which were obtained from the Cakung District Health Center. The instrument used in this study was a questionnaire containing the variables studied, such as the practice of washing hands with soap, using food serving aids, washing utensils, types of selling facilities, the presence of sanitation facilities, storage of cooked food, and serving methods. For the examination of E.coli bacteria in food, a qualitative laboratory test was carried out using Fluorocult LMX Broth media.

\section{RESULTS AND DISCUSSION}

\subsection{RESULT}

Cakung District is one of the special industrial areas, because the activities in the industrial sector are very dominant. In Cakung District there are large industries in the form of large factories and small industries in the form of home industries that produce various kinds of products. The largest land use in Cakung District is in the form of residential areas as much as $45.27 \%$ and industrial areas covering an area of $24.33 \%$. It is known that $45.2 \%$ of street foods that are positive for E.coli are sold by traders who do not practice hand washing with soap, while $44.4 \%$ of traders who practice handwashing with soap are sold positively containing E.coli. . Based on the results of statistical tests obtained $\mathrm{P}$ value of 1.00 ,

Table. 2 The Relationship between the Practice of Using Food Serving Aids and Contamination of

\begin{tabular}{|c|c|c|c|c|c|c|c|c|}
\hline \multirow{3}{*}{ Using Tools } & \multicolumn{4}{|c|}{ E.coli contamination } & \multicolumn{2}{|c|}{ Total } & \multirow{3}{*}{ Pvalue } & \multirow{3}{*}{ OR } \\
\hline & \multicolumn{2}{|c|}{ Positive } & \multicolumn{2}{|c|}{ Negative } & \multirow{2}{*}{$\mathbf{n}$} & \multirow{2}{*}{$\%$} & & \\
\hline & $\mathbf{n}$ & $\%$ & $\mathbf{n}$ & $\%$ & & & & \\
\hline No & 9 & 75 & 3 & 25 & 12 & 100 & 5.00 & 0.44 \\
\hline Yes & 18 & 37.5 & 30 & 62.5 & 48 & 100 & & $(1,195-20,922)$ \\
\hline
\end{tabular}

Based on the table. 2 it is known that $75 \%$ of snacks that are positive for E.coli are sold by traders who do not use food serving aids, while $37.5 \%$ of those who use food presentation aids are sold positively containing E.coli. Based on the results of statistical tests, a P-value of 0.044 was obtained, which means that at 5\% there was a significant relationship between using food serving aids and E.coli contamination in PJAS at Cakung District Elementary Schools in 2016. Food traders who did not use food serving aids risk 5.00 times greater can cause contamination of E.coli bacteria in the food it sells.

Table.3 Relationship between Equipment Washing Method and E.coli Bacteria Contamination in PJAS in Cakung District Elementary Schools

\begin{tabular}{|c|c|c|c|c|c|c|}
\hline \multirow{2}{*}{$\begin{array}{c}\text { How to Wash } \\
\text { Equipment }\end{array}$} & \multicolumn{3}{|c|}{ E.coli contamination } & \multicolumn{2}{|c|}{ Total } & \multirow[b]{2}{*}{ Pvalue } \\
\hline & Positive & & tive & n & $\%$ & \\
\hline
\end{tabular}

Contamination of Escherichia Coli Bacteria in Snack Food for School Children (PJAS) in Cakung District Elementary School, Hanifatun Nisa Ath Thoriqoh 


$\begin{array}{ccccccccc}\text { Terms Not Meet } & 19 & 47.5 & 21 & 52.5 & 40 & 100 & 1.357 & \\ \text { Eligible Conditions } & 8 & 40.0 & 12 & 60.0 & 20 & 100 & 0.783 & (0.457-4.032)\end{array}$

Based on the table. 3 it is known that traders who wash equipment that do not meet the requirements are $47.5 \%$ of the snacks sold are positive for E.coli while the traders who wash equipment that meet the requirements are $40 \%$ of the snacks sold are positive for E.coli. Based on the results of the statistical test, it was found that the P-value was 0.783 , which means that at $5 \%$ there was no significant relationship between how to wash equipment and E.coli contamination in PJAS in Cakung District Elementary Schools.

Table 4 The Relationship between Types of Selling Facilities and E.coli Contamination in PJAS in

\begin{tabular}{|c|c|c|c|c|c|c|c|c|}
\hline \multirow{4}{*}{ Types of Selling Means } & \multicolumn{8}{|c|}{ Cakung District Elementary Schools } \\
\hline & \multicolumn{4}{|c|}{ E.coli contamination } & \multicolumn{2}{|c|}{ Total } & \multirow{3}{*}{ Pvalue } & \multirow{3}{*}{ OR } \\
\hline & \multicolumn{2}{|c|}{ Positive } & \multicolumn{2}{|c|}{ Negative } & \multirow[b]{2}{*}{$\mathbf{n}$} & \multirow[b]{2}{*}{$\%$} & & \\
\hline & $\mathbf{n}$ & $\%$ & $\mathbf{n}$ & $\%$ & & & & \\
\hline Cart around the building & 12 & 41.4 & 17 & 58.6 & 29 & 100 & 0.775 & 0.753 \\
\hline canteen/kiosk & 15 & 48.4 & 16 & 51.6 & 31 & 100 & & $(0.271-2.090)$ \\
\hline
\end{tabular}

Based on the table. 4 , it is known that $41.4 \%$ of snacks that are positive for E.coli are sold by traders with a means of selling in the form of mobile carts, while for traders with means of selling in the form of canteen/kiosk buildings, $48.4 \%$ of snacks sold are positive for E.coli. . Based on the results of the statistical test, it was found that the P-value was 0.775 , which means that at $5 \%$ there was no significant relationship between the type of means of selling and the contamination of E.coli bacteria in PJAS at the Cakung District Elementary School.

Table. 5 The Relationship between the Presence of Sanitation Facilities and Contamination of E.coli Bacteria in PJAS at the Cakung District Elementary School

\begin{tabular}{|c|c|c|c|c|c|c|c|c|}
\hline \multirow{3}{*}{$\begin{array}{c}\text { Presence of Sanitation } \\
\text { Facilities }\end{array}$} & \multicolumn{4}{|c|}{ E.coli contamination } & \multicolumn{2}{|c|}{ Total } & \multirow{3}{*}{ Pvalue } & \multirow{3}{*}{ OR } \\
\hline & \multicolumn{2}{|c|}{ Positive } & \multicolumn{2}{|c|}{ Negative } & \multirow{2}{*}{$\mathbf{n}$} & \multirow{2}{*}{$\%$} & & \\
\hline & $\mathbf{n}$ & $\%$ & n & $\%$ & & & & \\
\hline & 16 & 44.4 & 20 & 55.6 & 36 & 100 & & 0.945 \\
\hline Eligible Conditions & 11 & 45.8 & 13 & 54.2 & 24 & 100 & 1.00 & $0.335-2.669)$ \\
\hline
\end{tabular}

Based on table 5, it is known that traders who have sanitation facilities that do not meet the requirements are $44.4 \%$ of the snacks sold are positive for E. .coli. Based on the results of statistical tests, it was obtained that the P-value was 1.00 , which means that at $5 \%$ there was no significant relationship between the presence of sanitation facilities and E.coli contamination in PJAS in SD Cakung District.

Table 5.6 Relationship between Food Storage and E.coli Bacteria Contamination in PJAS in Cakung

\begin{tabular}{|c|c|c|c|c|c|c|c|c|}
\hline \multirow{4}{*}{ Food Store } & \multicolumn{6}{|c|}{ District Elementary School } & \multirow{4}{*}{ Pvalue } & \multirow{4}{*}{ OR } \\
\hline & \multicolumn{4}{|c|}{ E.coli contamination } & \multicolumn{2}{|c|}{ Total } & & \\
\hline & \multicolumn{2}{|c|}{ Positive } & \multicolumn{2}{|c|}{ Negative } & \multirow{2}{*}{$\mathbf{n}$} & \multirow{2}{*}{$\%$} & & \\
\hline & $\mathbf{n}$ & $\%$ & $\mathbf{n}$ & $\%$ & & & & \\
\hline Terms Not Meet & 23 & 59.0 & 16 & 41.0 & 39 & 100 & & 6,109 \\
\hline Eligible Conditions & 4 & 19.0 & 17 & 81.0 & 21 & 100 & 0.007 & $(1,729-21,588)$ \\
\hline
\end{tabular}

Based on the table. 6 it is known that $59 \%$ of the traders who have food storage facilities that do not meet the requirements are positive for containing E.coli, while $19 \%$ of the traders who have food storage facilities that meet the requirements are positive for positive E.coli. Based on the results of statistical tests, a P-value of 0.007 was obtained, which means that at $5 \%$ there was a significant relationship between places to store cooked food and E.coli contamination in PJAS at SD Cakung District in 2016. Places to store food that did not meet the requirements were 6.109 times risky. cause E.coli contamination in snacks.

Table . 7 The Relationship between Food Presentation Method and E.coli Bacterial Contamination in PJAS in Cakung District Elementary School
How to Serve Food
E.coli contamination Total

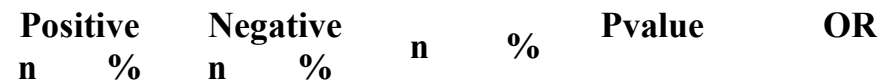




\begin{tabular}{lcccccccc}
\hline Terms Not Meet & 25 & 54.3 & 21 & 45.7 & 46 & 100 & & 7,143 \\
Eligible Conditions & 2 & 14.3 & 12 & 85.7 & 14 & 100 & 0.020 & $(1,434-35.57)$
\end{tabular}

Based on the table. 7 it is known that traders by serving food that do not meet the requirements are $54.3 \%$ of the snacks sold positively contain E.coli while the traders by serving food that meet the requirements are $14.3 \%$ of the snacks sold are positive to contain E.coli . Based on the results of statistical tests, a P-value of 0.020 was obtained, which means that at $5 \%$ there is a significant relationship between the way food is served and contamination with E.coli bacteria in PJAS at the Cakung District Elementary School in 2016. The method of serving that does not meet the requirements can risk 7.143 times being contaminated. bacteria than the proper presentation method.

\subsection{DISCUSSION}

The school in collaboration with the sub-district education office is advised to collect data and develop efforts for street food vendors who sell around the school. The school in collaboration with the local sub-district education office and other related parties is advised to empower and provide stimulants in the form of completeness of selling facilities such as sanitation facilities, trash cans, and other equipment. The school can put up posters related to food hygiene and safety in the school canteen.

Food vendors who sell using mobile facilities, such as mobile carts, are advised to store cooked food in a closed condition and frequently change the water in the buckets used for washing hands and utensils. Food traders who sell with immovable facilities, such as kiosks and canteen buildings, are advised to coordinate with the school to provide complete facilities for selling such as refrigerators for storing food, food processing equipment and closed trash cans.

Further researchers are advised to develop research by conducting rectal swab examinations, hand swabs, equipment swabs and clean water quality inspections to find out more clearly the source of bacterial contamination in food.

\section{CONCLUSION}

The results of the univariate analysis show that: $45 \%$ positive PJAS contaminated with E.coli bacteria, $70 \%$ of food handlers do not practice hand washing with soap, $80 \%$ of food handlers use food serving aids, $66.7 \%$ of the food handling equipment washing methods did not meet the requirements, $51.7 \%$ of food handlers use selling facilities in the form of canteen and kiosk buildings, $60 \%$ of the sanitation facilities owned by food handlers do not meet the requirements, $65 \%$ of places to store cooked food are not eligible and $76.7 \%$ of the way food is served does not meet the requirements. There was no relationship between the practice of washing hands with soap and E.coli contamination $(\mathrm{p}=1.00)$, there was a relationship between the practice of using food serving aids and E.coli contamination $(\mathrm{p}=0.044)$, there was no relationship between the method of washing the equipment with E.coli contamination $(p=0.783)$ and there was no relationship between the type of means of selling and contamination with E.coli bacteria $(p=0.775)$. There was no relationship between the presence of sanitation facilities and E.coli contamination $(\mathrm{p}=1.00)$, there was a relationship between where to store cooked food and E.coli contamination $(p=0.007)$ and there was a relationship between the way of presentation and contamination with E.coli bacteria $(p=0.02)$.

\section{REFERENCES}

[1] N. M. Afrah and I. M. Djaja, "Faktor Yang Memengaruhi Kontaminasi Bakteri Escherichia Coli Pada Makanan Jajanan Di Sekolah Dasar Kecamatan Beji, Kota Depok Tahun 2018," J. Nas. Kesehat. Lingkung. Glob., vol. 1, no. 2, 2020.

[2] D. P. Hutasoit, "Pengaruh Sanitasi Makanan dan Kontaminasi Bakteri Escherichia coli Terhadap Penyakit Diare," J. Ilm. Kesehat. Sandi Husada, vol. 12, no. 2, 2020, doi: 10.35816/jiskh.v12i2.399.

[3] A. Z. Diana, T. Triyanta, and W. Wartini, "Hubungan Higiene Penjamah dan Sanitasi Makanan dengan Kontaminasi Bakteri Escherichia Coli pada Makanan Jajanan di Samping SMP N 2 Sukoharjo," J. Ilmu Kesehat. Masy. Berk., vol. 2, no. 1, 2020, doi: 10.32585/jikemb.v2i1.814.

[4] A. Syafriyani and I. M. Djaja, "Hubungan Higiene Sanitasi Makanan Jajanan dengan Kontaminasi Escherichia Coli pada Makanan Jajanan Anak Sekolah Dasar di Kecamatan 
Medan Satria dan Kecamatan Jati Asih, Kota Bekasi Tahun 2018," J. Nasion al Keseh atan Lin gkungan Glob., vol. 1, no. 3, 2020.

[5] N. Noviana and A. Ruhban, "IDENTIFIKASI KANDUNGAN BAKTERI Escherichia coli dan Salmonella PADA BURGER YANG DIJUAL PEDAGANG KAKI LIMA DI KOTA MAKASSAR," Sulolipu Media Komun. Sivitas Akad. dan Masy., vol. 19, no. 2, 2020, doi: 10.32382/sulolipu.v19i2.1348.

[6] Y. S. Supriatin, F. F. Fadhilah, and V. A. Sumirat, "Penyimpanan Bakteri Escherichia coli Dan Streptococcus pneumonie Pada Media Cryoprotective Dengan Metode Freeze Drying," Quagga J. Pendidik. dan Biol., vol. 12, no. 1, 2020, doi: 10.25134/quagga.v12i1.2148.

[7] I. D. A. K. Yunantariningsih, N. M. A. S. Singapurwa, I. W. Sudiarta, I. N. Rudianta, and I. P. Candra, "Analisis Pemanis Buatan Sakarin Pada Pangan Jajanan Anak Sekolah Dasar Di Kecamatan Denpasar Selatan," Univ. Dhyana Putra SINTESA Pros. 2019, 2019.

[8] D. I. Ningtyas and S. Darmawan, "Hubungan Karakteristik, Pengetahuan Gizi, Dan Sikap Terhadap Penjaja Makanan Di Kantin Sdn Jakarta Timur,” Binawan Student Journal. 2019.

[9] desi rahmalia yeti miratania, "Faktor-faktor yang Berhubungan dengan Perilaku Pedagang dalam Penggunaan Bahan Tambahan Pangan Jajanan Anak Sekolah di SDN TelukPucung VII Kota Bekasi Tahun 2019," J. Kesehat. Masy., vol. 3, no. 2, 2019.

[10] D. P. Mayaserli and D. Anggraini, "IDENTIFIKASI BAKTERI Escherichia Colli PADA JAJANAN BAKSO TUSUK DI SEKOLAH DASAR KECAMATAN GUNUNG TALANG," J. Kesehat. PERINTIS (Perintis's Heal. Journal), vol. 6, no. 1, 2019, doi: 10.33653/jkp.v6i1.220.

[11] L. Banterang, "Kontaminasi Bakteriologis Escherichia coli Dalam Air Minum Isi Ulang Di Beberapa Kota Di Indonesia," 2020.

[12] S. Hidayati, "PENYULUHAN KEAMANAN PANGAN JAJANAN ANAK SEKOLAH DI SD MIFTAHUL JANNAH BANDAR LAMPUNG," Sakai Sambayan J. Pengabdi. Kpd. Masy., vol. 3, no. 3, 2019, doi: 10.23960/jss.v3i3.167. 